\title{
Processing of Landsat 8 Imagery and Ground Gamma-Ray Spectrometry for Geologic Mapping and Dose-Rate Assessment, Wadi Diit along the Red Sea Coast, Egypt
}

\author{
Ahmed E. Abdel Gawad*, Atef M. Abu Donia, Mahmoud Elsaid \\ Nuclear Materials Authority, Cairo, Egypt \\ Email: "drahmed_abdelgawad@hotmail.com \\ Received 2 July 2016; accepted 26 August 2016; published 29 August 2016 \\ Copyright (C) 2016 by authors and Scientific Research Publishing Inc. \\ This work is licensed under the Creative Commons Attribution International License (CC BY). \\ http://creativecommons.org/licenses/by/4.0/

(c) (i) Open Access

\begin{abstract}
Maximum Likelihood (MLH) supervised classification of atmospherically corrected Landsat 8 imagery was applied successfully for delineating main geologic units with a good accuracy (about $\mathbf{9 0 \% )}$ according to reliable ground truth areas, which reflected the ability of remote sensing data in mapping poorly-accessed and remote regions such as playa (Sabkha) environs, subdued topography and sand dunes. Ground gamma-ray spectrometric survey was to delineate radioactive anomalies within Quaternary sediments at Wadi Diit. The mean absorbed dose rate (D), annual effective dose equivalent (AEDE) and external hazard index $\left(\mathrm{H}_{\mathrm{ex}}\right)$ were found to be within the average worldwide ranges. Therefore, Wadi Diit environment is said to be radiological hazard safe except at the black-sand lens whose absorbed dose rate of $100.77 \mathrm{nGy} / \mathrm{h}$ exceeds the world average. So, the inhabitants will receive a relatively high radioactive dose generated mainly by monazite and zircon minerals from black-sand lens.
\end{abstract}

\section{Keywords}

Landsat 8 Imagery, Image Processing, Maximum Likelihood Classification, Environmental Monitoring, Absorbed Dose Rate, Hazard Index

\section{Introduction}

The environmental radioactivity monitoring programs started in late 1950 's of the $20^{\text {th }}$ century following the

${ }^{*}$ Corresponding author.

How to cite this paper: Abdel Gawad, A.E., Abu Donia, A.M. and Elsaid, M. (2016) Processing of Landsat 8 Imagery and Ground Gamma-Ray Spectrometry for Geologic Mapping and Dose-Rate Assessment, Wadi Diit along the Red Sea Coast, Egypt. Open Journal of Geology, 6, 911-930. http://dx.doi.org/10.4236/ojg.2016.68069 
global fallout from testing of nuclear weapons in the atmosphere, becoming a cause of concern regarding health effects. Later, the necessity of world industrialization for new energy sources led to develop national plans on electricity production from nuclear technology, initializing in this context worldwide exploration for fuel minerals: uranium exploration gained a particular attention in late 1940's in USA, Canada and former USSR and in 1951 in Australia with respective national plans [1].

The principal sources of environmental radioactivity of monitoring interest are due to the presence of ${ }^{238} \mathrm{U}$, ${ }^{232} \mathrm{Th}$ and ${ }^{40} \mathrm{~K}$ in the Earth's crust. Generally, other major and trace elements like ${ }^{235} \mathrm{U}$ and ${ }^{87} \mathrm{Rb}$ are negligible for radioactivity monitoring purposes. The world average abundances of the continental upper crust for ${ }^{238} \mathrm{U}$, ${ }^{232} \mathrm{Th}$ and ${ }^{40} \mathrm{~K}$ are respectively $2.7 \mathrm{ppm}, 10.5 \mathrm{ppm}$ and $2.3 \%$ [2]. Many countries have already monitored the distribution of natural radioactivity, finalized with the construction of the radiometric maps of their territories (USA, Canada, Australia, Switzerland, Slovakia, Slovenia, Czech Republic, UK, etc.). Gamma-rays are the most penetrating radiation from natural and man-made sources. It is a powerful tool for the monitoring and assessment of the radiation environment. It is widely used in geological mapping, soil surveying, mineral exploration and regolith studies. The use of the method as a mapping tool requires an understanding of the geochemistry of the radio elements in rocks and soils and the processes that effect their distribution and mobility [1].

Airborne and spaceborne remote sensing techniques are of great interest especially in poor accessible remote regions such as playa (Sabkha) environs, subdued topography and sand dunes [3]-[7].

Multispectral data like Landsat 7 Enhanced Thematic Mapper Plus (ETM+) and Advanced Spaceborne Thermal Emission and Reflection Radiometer (ASTER) were successfully used for mapping landcover types in playa regions [3] [8] [9].

The modern Landsat 8 (L8) sensor provides multispectral imagery data of higher spectral (11 bands) and radiometric (16-bit) resolutions than the commonly used Landsat 5 and 7. The main objective of the present work is using remote sensing technique (Landsat 8 data processing) integrated with detailed field geology and ground gamma-ray spectrometric survey for geologic mapping and detecting radioactive anomalies as well as dose-rate assessment of alluvial fan Quaternary sediments in a poor-accessible desert area (Wadi Diit) along the Red Sea coast in the southeastern part of Egypt.

\section{Geomorphologic Setting}

Wadi Diit alluvial fan sediments is located at the southern part of Shlatin town by about $70 \mathrm{~km}$ along the Red Sea coastal plain. It drains a vast area from the central part of the Sudanese Eastern Desert. It is located in the southeastern part of Egypt, between latitudes $22^{\circ} 23^{\prime} 00^{\prime \prime} \mathrm{N}-22^{\circ} 39^{\prime} 00^{\prime \prime} \mathrm{N}$ and longitudes $36^{\circ} 4^{\prime} 00^{\prime \prime} \mathrm{E}-36^{\circ} 15^{\prime} 00^{\prime \prime} \mathrm{E}$ (Figure 1). The studied area is generally characterized by an arid climate. It has a gentle topography, thick cultivation and is divided by a dendritic seasonal drainage network. It has a triangular shape with its apex at about $40 \mathrm{~km}$ from the Red Sea shoreline forming an alluvial fan. This fan is considered as one of the most obvious geomorphic landform along the foot-slopes of the Red Sea mountains.

\section{Remote Sensing Data Analysis and Results}

\subsection{Landsat 8 Imagery}

Landsat Data Continuity Mission (LDCM) was launched atop an Atlas V rocket on February 11, 2013, and then named Landsat 8 (L8) after on-orbit initialization and verification by May 30, 2013. L8 has two eyes (instruments); Operational Land Imager (OLI) and Thermal Infrared Sensor (TIRS) [10] (Table 1). The OLI has a nine band push-broom sensor (eight bands at $30 \mathrm{~m}$ and one panchromatic band at $15 \mathrm{~m}$ ), with a four mirror telescope, higher signal-to-noise performance than older Landsat generations, radiometric resolution of 12-bit up to 16-bit (instead of 8-bit in the former Landsat $5 \&$ 7) and a swath width of $185 \mathrm{~km}$. TIRS collects data in two long wavelength thermal infrared bands of $100 \mathrm{~m}$ spatial resolution. TIRS data is registered to the OLI data to create radiometrically and geometrically calibrated, terrain-corrected Level 1 data products, raising their radiometric resolution to 16-bit [11]-[13].

Landsat 8 L1T (terrain corrected) scene (Table 2), nearly cloud free, covering the study area, was obtained from USGS EarthExplorer site (http://earthexplorer.usgs.gov/). Processing methods carried out using ENVI (Environment for visualizing images) V. 5.1 and layout by ArcGIS V. 10.2. 


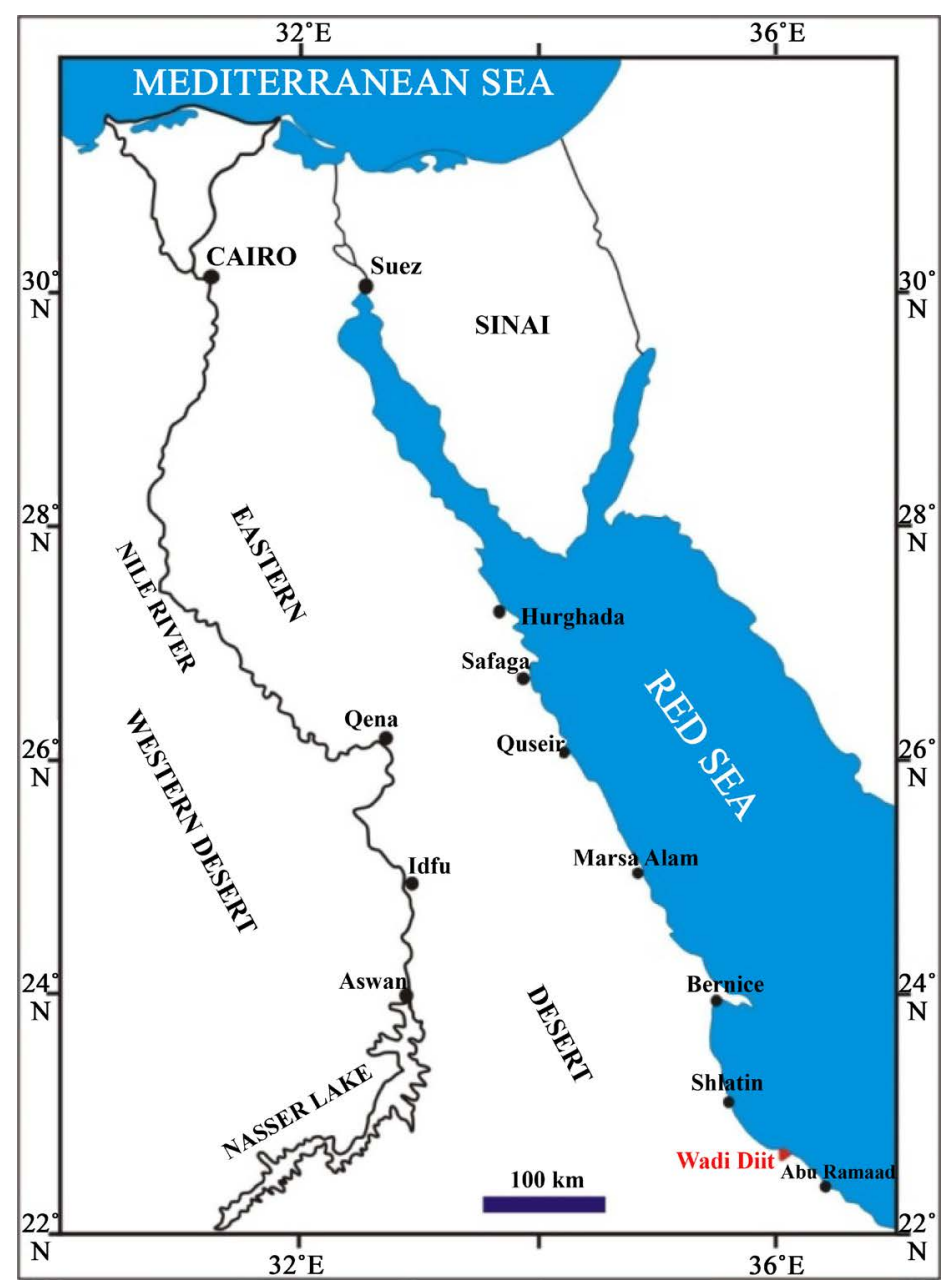

Figure 1. Location map of Wadi Diit along the Red Sea coast, Egypt.

Table 1. Landsat 8 (OLI and TIRS) bands and their Landsat 7 equivalents [10].

\begin{tabular}{|c|c|c|c|c|c|}
\hline Landsat 8 Bands ${ }^{*}$ & $\begin{array}{c}\text { Landsat } 8 \text { Bandwidth } \\
(\mu \mathrm{m})\end{array}$ & $\begin{array}{l}\text { Wavelength Center } \\
(\mu \mathrm{m})\end{array}$ & $\begin{array}{l}\text { Spatial Resolution } \\
\text { (m) }\end{array}$ & $\begin{array}{c}\text { Equivalent Landsat } 7 \\
\text { Bands }\end{array}$ & $\begin{array}{c}\text { Radiometric } \\
\text { Resolution }\end{array}$ \\
\hline 1 (Coastal/Aerosol) & $0.433-0.453$ & 0.4430 & 30 & - & \multirow{11}{*}{ 12-bit ${ }^{* * *}$} \\
\hline 2 (Blue) & $0.450-0.515$ & 0.4826 & 30 & 1 & \\
\hline 3 (Green) & $0.525-0.600$ & 0.5613 & 30 & 2 & \\
\hline 4 (Red) & $0.630-0.680$ & 0.6546 & 30 & 3 & \\
\hline $5(N I R)$ & $0.845-0.885$ & 0.8646 & 30 & 4 & \\
\hline $6(S W I R 1)$ & $1.560-1.660$ & 1.6090 & 30 & 5 & \\
\hline 7 (SWIR2) & $2.100-2.300$ & 2.2010 & 30 & 7 & \\
\hline 8 (Panchromatic) & $0.500-0.680$ & 0.5917 & 15 & 8 & \\
\hline 9 (Cirrus) & $1.360-1.390$ & 1.3730 & 30 & - & \\
\hline 10 (TIRS1) & $10.60-11.19$ & 10.9 & \multirow{2}{*}{$100^{* *}$} & \multirow{2}{*}{$6(\mathrm{~L} \& \mathrm{H})$} & \\
\hline 11 (TIRS2) & $11.50-12.51$ & 12.0 & & & \\
\hline
\end{tabular}

${ }^{*}$ Landsat 8 provides additional Quality Assessment band used to reduce instrumental artifacts and cloud contamination. ${ }^{* *}$ TIRS bands are acquired at 100 meter resolution, but are resampled to 30 meter in delivered data product. ${ }^{* * *}$ Increased to 16 -bit in Level 1 data products.

Table 2. Landsat 8 L1T (terrain corrected) scene used in the current study.

\begin{tabular}{cccccc}
\hline L8 Scene No. & Date & Time & Cloud Cover & Level \\
\hline LC81720442013107LGN01 & April 17, 2013 & $08: 02: 57$ & $0.08 \%$ & L1T (Terrain Corrected) \\
\hline
\end{tabular}




\subsection{Data Preprocessing}

Preprocessing techniques including converting Landsat 8 calibrated digital numbers (DNs) to physical units, such as sensor radiance and surface reflectance (SR), using landsat calibration and Fast Line-of-Sight Atmospheric Analysis of Spectral Hypercubes (FLAASH) tools of ENVI software were applied. A flowchart that summarizes the used preprocessing scheme of Landsat 8 OLI data is shown on (Figure 2).

The Minimum Noise Fraction (MNF) transform [14] was used to determine the inherent dimensionality of image data, segregate and equalize the noise in data (increasing signal-to-noise $[\mathrm{S} / \mathrm{N}]$ ratio), and diminish the computational requirements for subsequent processing [15]. In the current study, forward MNF transformation was applied on the Landsat 8 OLI bands (cirrus band was excluded) and the eigenvalues of the seven output MNF eigenimages are displayed on (Table 3). The first three eigenimages provide more than $97 \%$ of eigenvalues and/or spectral information, while the rest eigenimages provide just 3\%. Eigenimages with values near unity are normally noise-dominated [16]. In the current study, the eigenimages that possess eigenvalue less than two (MNF7) were excluded during inverse MNF transformation, giving seven reflectance bands with higher S/N ratio (Figure 3).

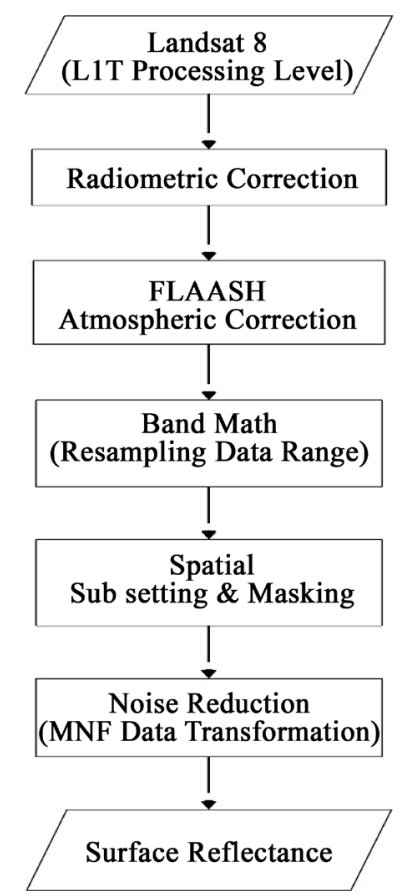

Figure 2. Preprocessing scheme of Landsat 8 OLI data.

Table 3. Resulted MNFs and their eigenvalues.

\begin{tabular}{|c|c|c|c|c|c|}
\hline MNF (Eigenvalue Number) & Eigenvalue & Percent & & Graph & \\
\hline MNF1 & 689.66 & 85.31 & & MNF File: masked DiitSR.tif & \\
\hline MNF2 & 67.08 & 8.30 & 600 & & \\
\hline MNF3 & 27.70 & 3.43 & $\stackrel{0}{\Xi} 500=$ & & \\
\hline MNF4 & 10.72 & 1.33 & 总 $300=$ & & \\
\hline MNF5 & 8.82 & 1.09 & $200=$ & & \\
\hline MNF6 & 2.79 & 0.34 & 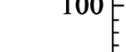 & & \\
\hline MNF7 & 1.68 & 0.21 & & $\begin{array}{ccc}3 & 1 & 1 \\
\text { Eigenvalue Number }\end{array}$ & 7 \\
\hline
\end{tabular}




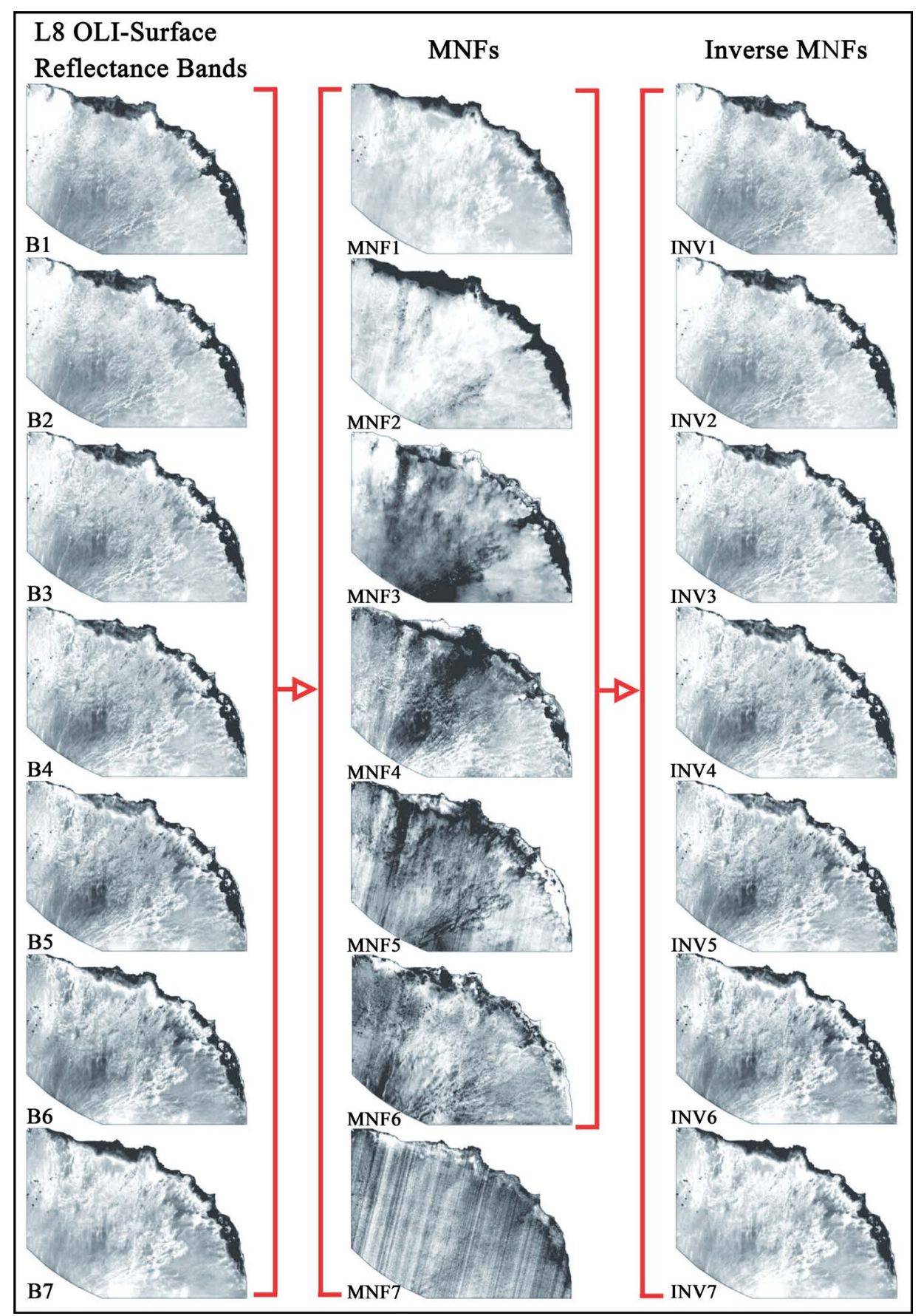

Figure 3. Increasing S/N ratio (noise reduction) through forward and inverse MNF transformation of L8-OLI surface reflectance bands covering study area. MNF7 component (the noisiest) was excluded.

Natural Color Composite image of bands 4, 3, 2 in RGB and False Color Composite (FCC) image of bands 7, 5, 3 in RGB covering the study area are shown on Figure 4 and Figure 5, respectively. FCC provides a more colorful contrasted image (than the natural color composite) differentiating the different lithologic units within the study area.

\subsection{Data Classification and Mapping}

Although multi-spectral images (like L8 imagery) could be treated as one multi-variable dataset and so 


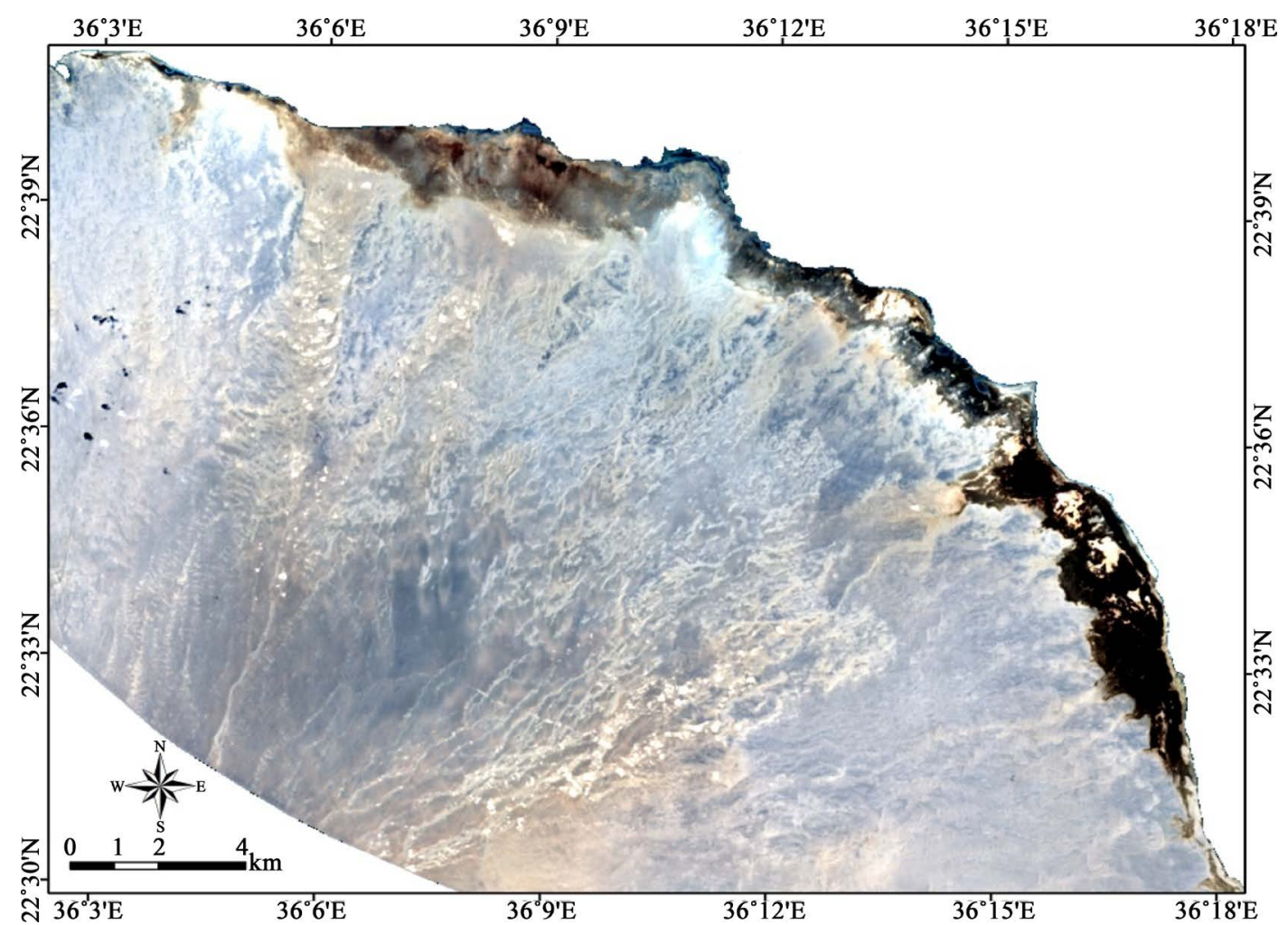

Figure 4. Natural color composite image of Landsat 8 OLI bands 4, 3, 2 in RGB of Wadi Diit along the Red Sea coast, Egypt.

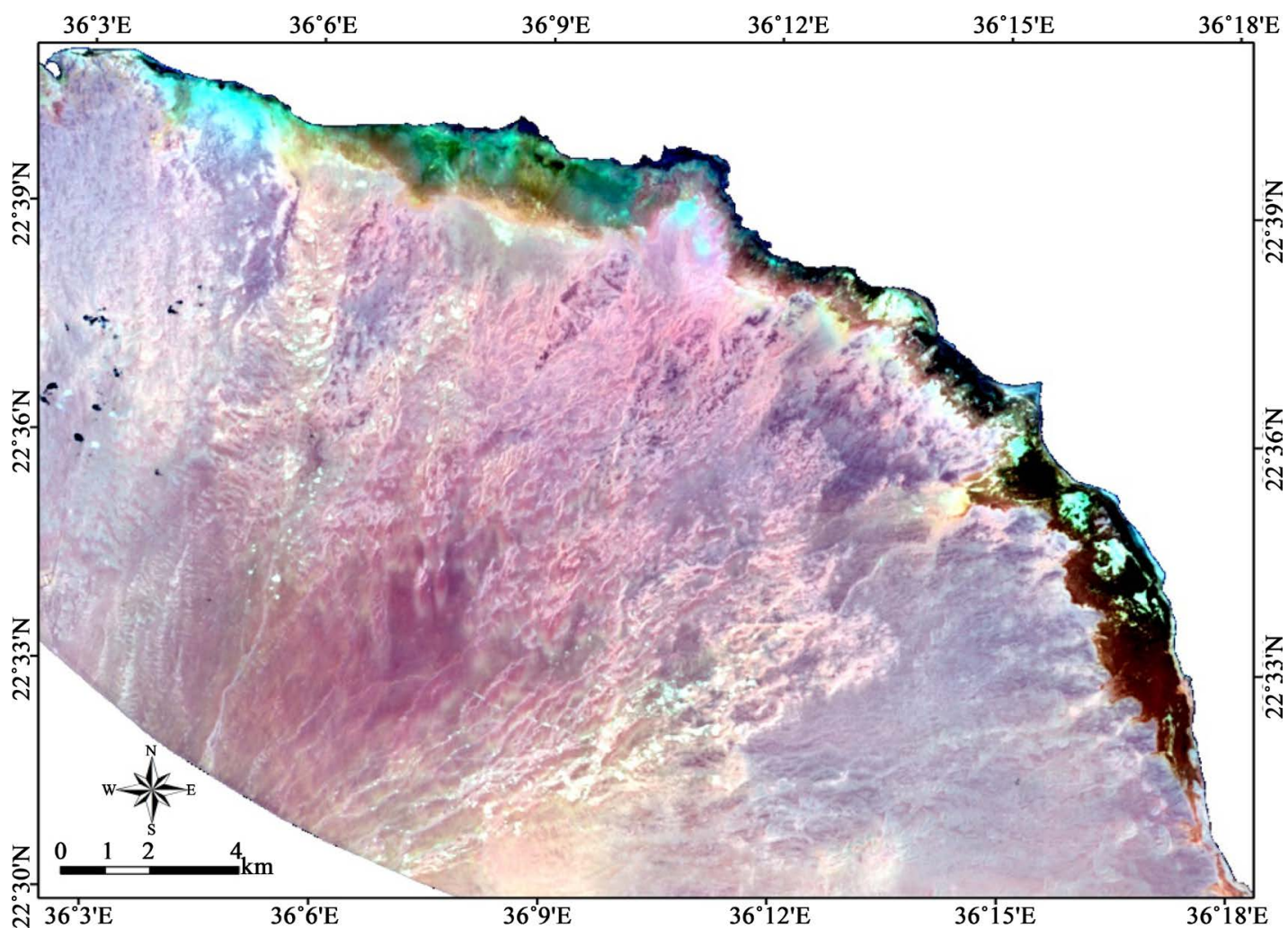

Figure 5. False color composite (FCC) image of Landsat 8 OLI bands 7, 5, 3 in RGB of Wadi Diit along the Red Sea coast, Egypt. 
unsupervised statistical classification algorithms (like isocluster analysis) could be applied to produce classification maps, but in many cases this cannot disregard the visual interpretation and field observations [17]. So, the first step for applying any supervised classification method is to determine the endmembers of the different landcover types. 2D-scatter plot of noncorrelated reflectance bands (bands 7 and 5) (Figure 6) along with the aid of training field sites, regions of interest (ROIs), over the different landcover types identified through the geologic field work were used; the used ROIs and their average spectrum of each are represented on Figure 7(a) and Figure 7(b).

The reference endmembers show an overall similarity in their spectral curves with a general convergence and low absorption troughs at coastal blue and blue bands. On the other hand, there is a gradual increase in both surface reflectances and radiometric separations towards longer wavelengths especially at SWIR bands (6 and 7). Costal-Eolian Sabkha endmember implies a general decrease in its reflectance values allover bands compared with other endmembers, which may be originated from its water content (moisture or sea water), which absorbs most of the reflected wavelengths.

Maximum likelihood classification is a commonly used supervised classification method. It is based on Bayes' theorem that assumes a normal distribution for all clusters and calculates the probability that a given pixel belongs to a specific class [17]. The method was used successfully in classifying lithologic units of the study area after masking clouds and their shades at the western fringes, according to the selected ROIs, giving a supervised classification image (Figure 8). ENVI's post classification algorithm, Majority/Minority analysis, was then used to change spurious pixels within a large single class to that class. A confusion (contingency) matrix was carried out to assess the accuracy of classification results, using ground truth information collected through field check, an overall accuracy of $89.51 \%$ and kappa coefficient of 0.86 were resulted (Table 4).

\section{Geologic Setting}

The integrated data between Landsat 8 and detailed field investigation were used to identify the exposed rock types at Wadi Diit area (Figure 9). They show that the exposed rock units in the alluvial fan of the study area are mostly composed of Quaternary sediments, which comprise unconsolidated wadi sediments, costal-eolian sabkhas, sandy conglomerates, sandy dunes and sheets, mud cracks and black-sand lens.

Wadi sediments are mostly comprised sands and gravels, which are broadly categorized as undifferentiated wadi alluvium on the map sheet. They include outwash sediments, channel fill, terraced piedmont sands and gravels of angular, subangular, subrounded to rounded fragments of serpentinite, metagabbros, metavolcanics, Hamammat sediments, older and younger granites, felsite and quartz.

Sabkha is the Arabic term adopted by geologists for low-lying salt flats subject to periodic inundation. An

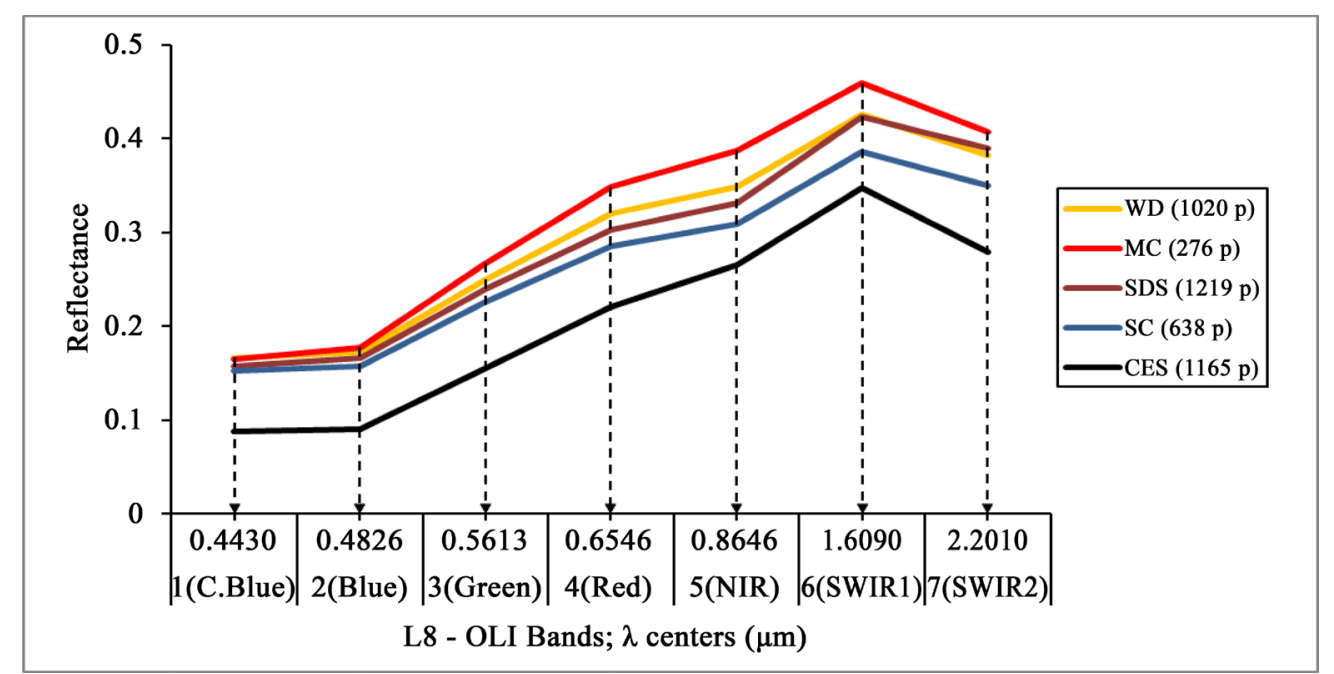

Figure 6. Endmembers (average reflectances of selected ROIs) used in supervised classification process; where: WD (1020 p) = Average spectrum of 1020 selected pixels on Wadi Sediments, MC (276 p) = Average spectrum of 276 selected pixels on Mud Cracks, SDS (1219 p) = Average spectrum of 1219 selected pixels on Sand Dunes and Sheets, SC $(638 \mathrm{p})=$ Average spectrum of 638 selected pixels on Sandy Conglomerates, CES (1165 p) = Average spectrum of 1165 selected pixels on Costal-Eolian Sabkhas, Wadi Diit along the Red Sea coast, Egypt. 

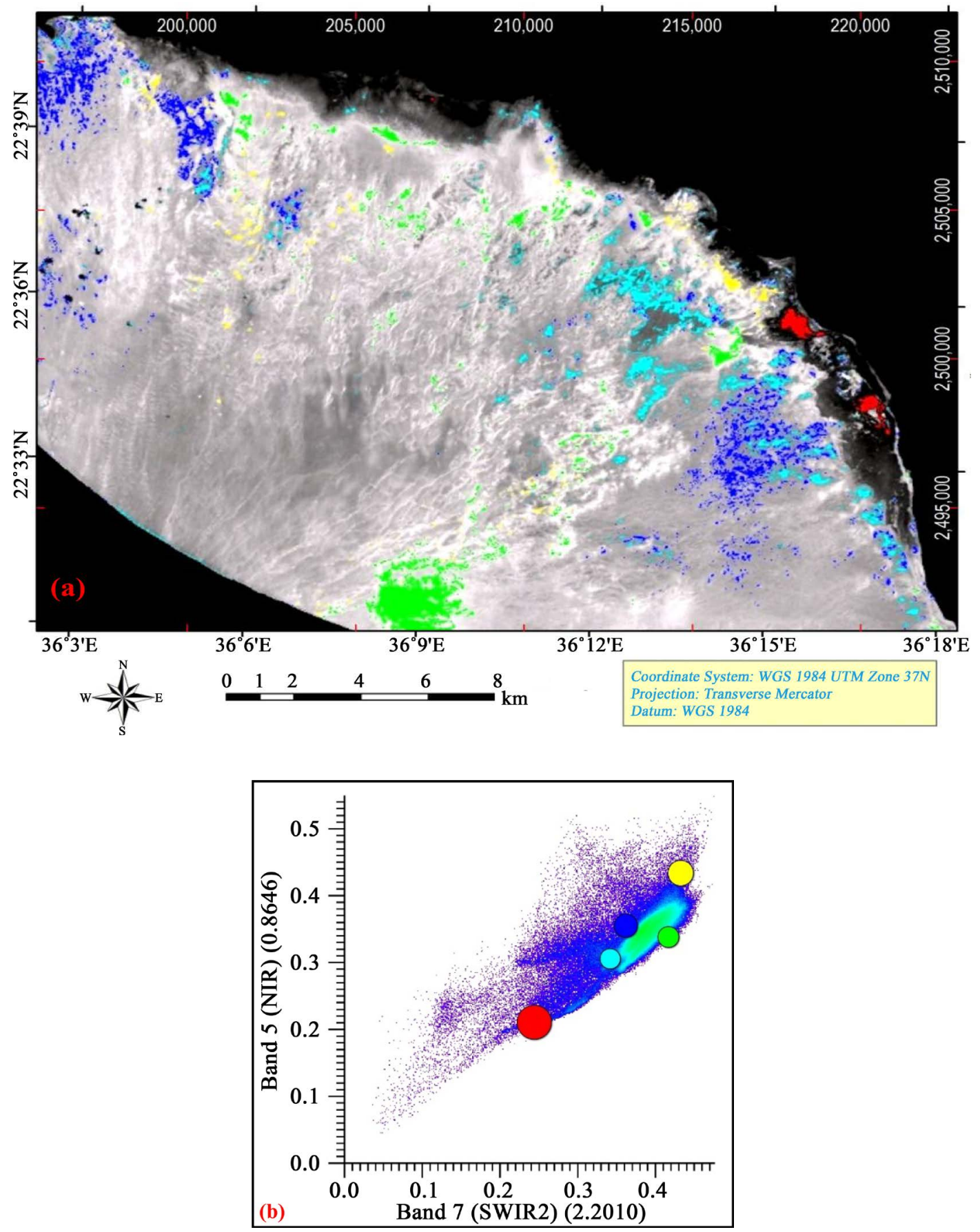

Figure 7. Band 7 - Band 5 2D scatter plot used for selecting endmembers (ROIs) at the extreme pixels as following: Wadi Sediments (Blue), Coastal-Eolian Sabkha (Red), Sandy Conglomerate (Cyan), Sand Dunes and Sheets (Green), Mud Cracks (Yellow).

irregular, buffy crust of loosely cemented salts, fine sediment is common on dry sabkha and macroscopic marine organism remnants (Figure 10(a) and Figure 10(b)). Expansion due to the crystallization of salts may create raised polygonal patterns, whereas shrinkage due to desiccation may create polygonal "mud cracks". Sabkha plain and salt encrustations are formed due to the invasion of sea water during high tides. In the studied area the sabkha may extend more than $40 \mathrm{~km}$ along the Red Sea shoreline and 4 to $5 \mathrm{~km}$ width inland. The coastal sabkha is extremely flat above the level of normal high tides. 


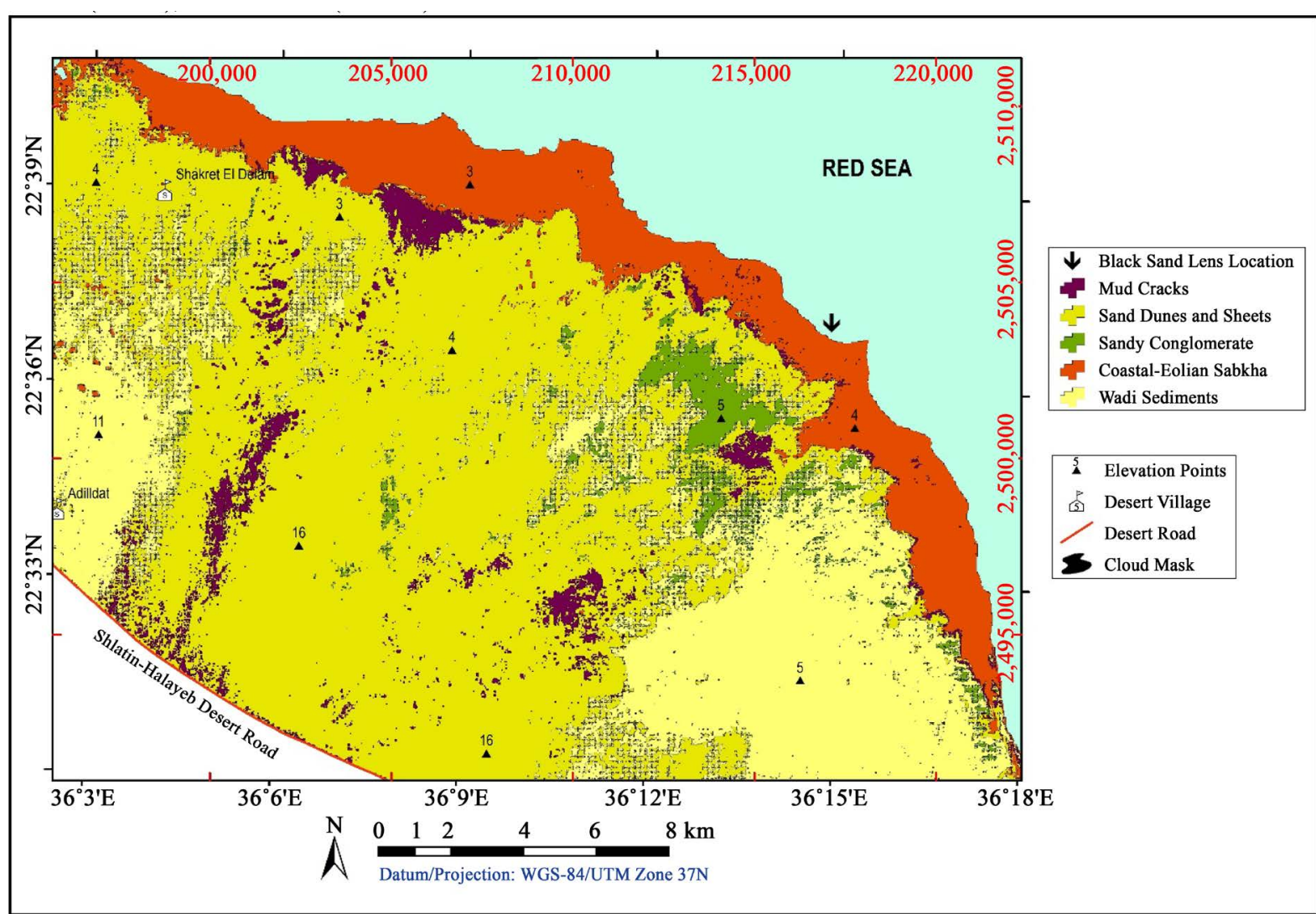

Figure 8. Maximum likelihood supervised classified image of Wadi Diit along the Red Sea coast, Egypt.

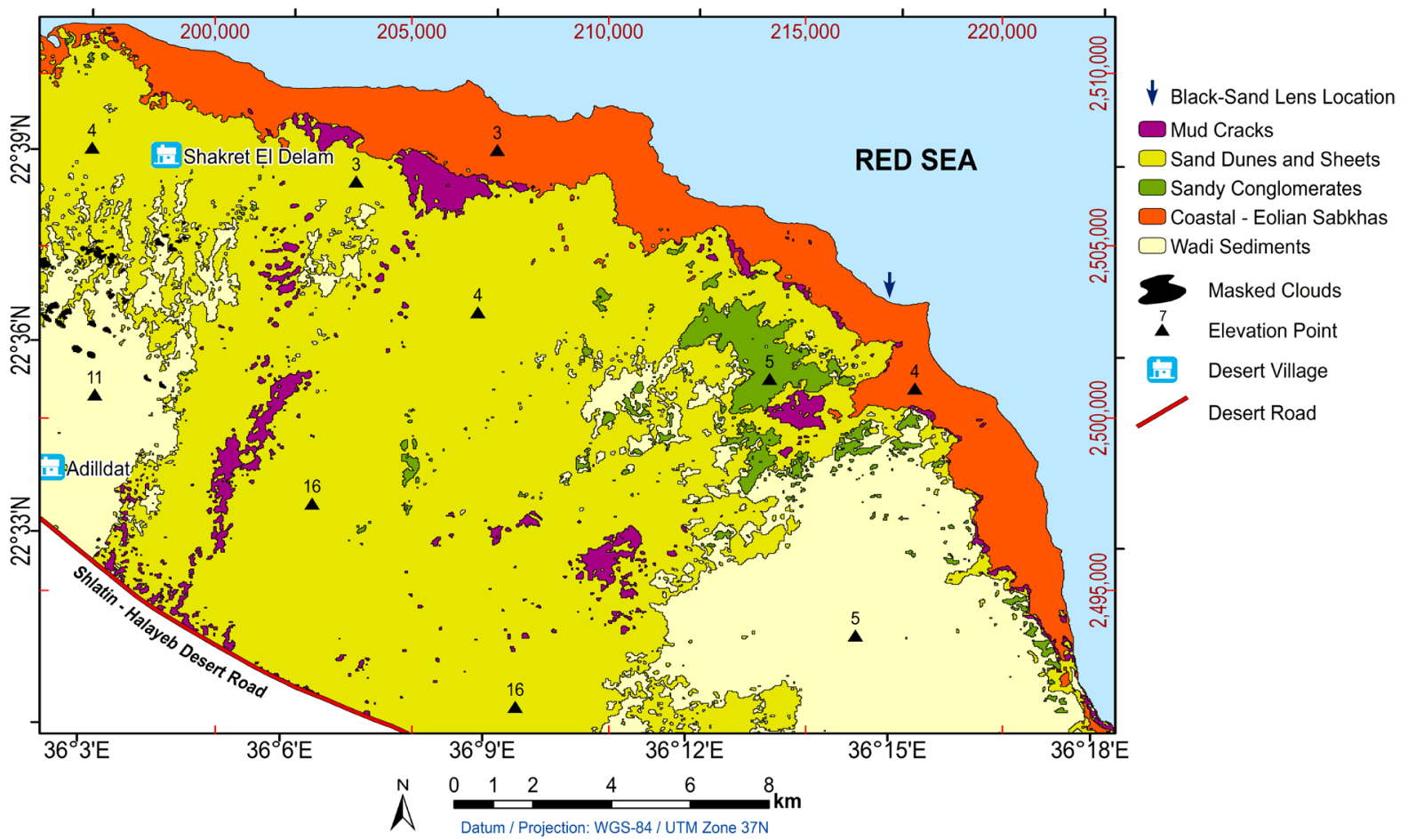

Figure 9. Compiled geologic map of Wadi Diit along the Red Sea coast, Egypt interpreted from supervised classified Landsat 8 image. 
Table 4. Confusion matrix explains the accuracy assessment of classification.

\begin{tabular}{|c|c|c|c|c|}
\hline \multicolumn{5}{|c|}{$\begin{array}{l}\text { Overall Accuracy }=(6286 / 7023) 89.5059 \% \\
\text { Kappa Coefficient }=0.8647\end{array}$} \\
\hline \multicolumn{5}{|c|}{ Ground Truth (Pixels) } \\
\hline Class & CES & SC & WS & MC \\
\hline Unclassified & 0 & 0 & 0 & 0 \\
\hline Coastal Eolian Sabkha (CES) & 2107 & 0 & 30 & 0 \\
\hline Sandy Conglomerate (SC) & 0 & 1439 & 0 & 0 \\
\hline Sand Dunes and Sheets (SDS) & 16 & 94 & 48 & 268 \\
\hline Wadi Sediments (WS) & 7 & 108 & 1275 & 0 \\
\hline Mud Cracks (MC) & 127 & 0 & 0 & 1053 \\
\hline Total & 2257 & 1641 & 1353 & 1321 \\
\hline \multicolumn{5}{|c|}{ Ground Truth (Percent) } \\
\hline Class & CES & SC & WS & MC \\
\hline Unclassified & 0.00 & 0.00 & 0.00 & 0.00 \\
\hline Coastal Eolian Sabkha (CES) & 93.35 & 0.00 & 2.22 & 0.00 \\
\hline Sandy Conglomerate (SC) & 0.00 & 87.69 & 0.00 & 0.00 \\
\hline Sand Dunes and Sheets (SDS) & 0.71 & 5.73 & 3.55 & 20.29 \\
\hline Wadi Sediments (WS) & 0.31 & 6.58 & 94.24 & 0.00 \\
\hline Mud Cracks (MC) & 5.63 & 0.00 & 0.00 & 79.71 \\
\hline Total & 100.00 & 100.00 & 100.00 & 100.00 \\
\hline \multicolumn{2}{|c|}{ Ground Truth (Pixels) } & \multicolumn{3}{|c|}{ Ground Truth (Percent) } \\
\hline Class & Total & \multicolumn{2}{|c|}{ Class } & Total \\
\hline Unclassified & 0 & \multicolumn{2}{|c|}{ Unclassified } & 0.00 \\
\hline Coastal Eolian Sabkha (CES) & 2137 & \multicolumn{2}{|c|}{ Coastal Eolian Sabkha (CES) } & 30.43 \\
\hline Sandy Conglomerate (SC) & 1439 & \multicolumn{2}{|c|}{ Sandy Conglomerate (SC) } & 20.49 \\
\hline Sand Dunes and Sheets (SDS) & 838 & \multicolumn{2}{|c|}{ Sand Dunes and Sheets (SDS) } & 11.93 \\
\hline Wadi Sediments (WS) & 1395 & \multicolumn{2}{|c|}{ Wadi Sediments (WS) } & 19.86 \\
\hline Mud Cracks (MC) & 1214 & \multicolumn{2}{|c|}{ Mud Cracks (MC) } & 17.29 \\
\hline Total & 7023 & \multicolumn{2}{|c|}{ Total } & 100.00 \\
\hline Class & Commission (Percent) & Omission (Percent) & Commission (Pixels) & Omission (Pixels) \\
\hline Coastal Eolian Sabkha (CES) & 1.40 & 6.65 & $30 / 2137$ & $150 / 2257$ \\
\hline Sandy Conglomerate (SC) & 0.00 & 12.31 & $0 / 1439$ & $202 / 1641$ \\
\hline Sand Dunes and Sheets (SDS) & 50.84 & 8.65 & $426 / 838$ & $39 / 451$ \\
\hline Wadi Sediments (WS) & 8.60 & 5.76 & 120/1395 & $78 / 1353$ \\
\hline Mud Cracks (MC) & 13.26 & 20.29 & $161 / 1214$ & $268 / 1321$ \\
\hline Class & Prod. Acc. (Percent) & User Acc. (Percent) & Prod. Acc. (Pixels) & User Acc. (Pixels) \\
\hline Coastal Eolian Sabkha (CES) & 93.35 & 98.60 & $2107 / 2257$ & $2107 / 2137$ \\
\hline Sandy Conglomerate (SC) & 87.69 & 100.00 & $1439 / 1641$ & $1439 / 1439$ \\
\hline Sand Dunes and Sheets (SDS) & 91.35 & 49.16 & $412 / 451$ & $412 / 838$ \\
\hline Wadi Sediments (WS) & 94.24 & 91.40 & $1275 / 1353$ & $1275 / 1395$ \\
\hline Mud Cracks (MC) & 79.71 & 86.74 & $1053 / 1321$ & $1053 / 1214$ \\
\hline
\end{tabular}

- Kappa Coefficient: Cohen's kappa (k) is commonly used for accuracy assessment. For example, these are useful when building models that predict discrete classes or classifying imagery. They help provide a sense of how accurate or useful the model is. 

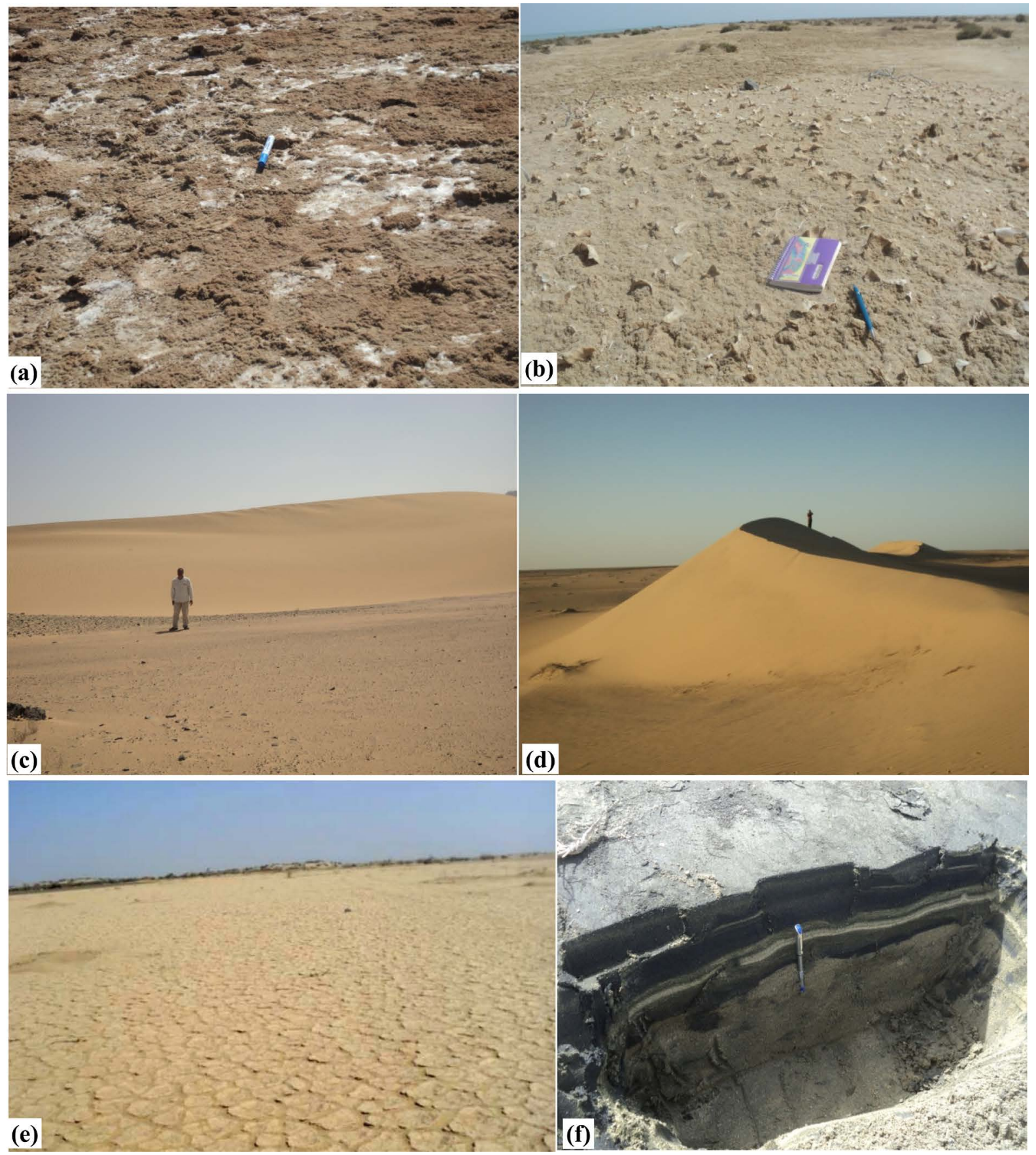

Figure 10. Field photos showing different geomorphologic and geologic features at Wadi Diit along the Red Sea coast, Egypt. (a) Sabkha plain and salt encrustations on the Red Sea coast. (b) Macroscopic marine organism remnants on the Red Sea sabkha plain. (c) Coastal sand dune on the Red Sea coastal plain. (d) Loose sand indicating barchan type. (e) Mud crack formation related to clayey soils upon drying. (f) Box cut in black-sand lens on the Red Sea coast showing that the thickness ranges between 0.4 and $1.0 \mathrm{~m}$.

Three general types were recognized, on the basis of dominant physical processes of their environmental formation (Figure 11) [18] [19].

1) Coastal marine: Coastal sabkha, as the name implies, forms at or near the marine shoreline.

2) Lacustrine/playa: It is formed in association with river or lake drainage systems in arid areas.

3) Eolian/interdunal: Inland or interdunal sabkha is found in low-lying basins within the sand desert. 


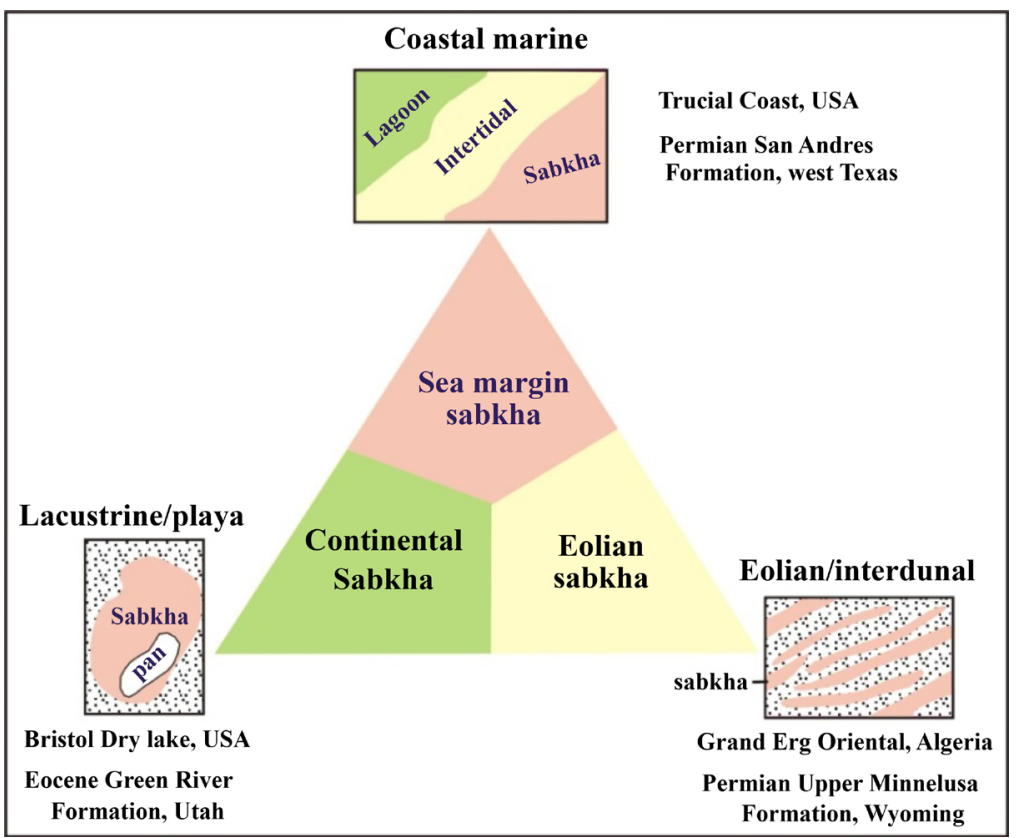

Figure 11. Sabkha classification using depositional setting of matrix material [18] [19].

Wadi Diit sabkha plain is costal-eolian dominated which distinguished by a mixture of sediments comprising salts, carbonate-sulfate and mud (Figure 10(a) and Figure 10(b)).

Sandy conglomerates are composed mainly of basement fragments of different size range between 30 and 60 $\mathrm{cm}$, of angular, subangular, subrounded to rounded shapes embedded in yellowish friable sands.

The major sand dunes and sheets belt are found in the eastern part of the studied area. Their formation is controlled by a combination of wind strength and direction, as well as sediment supply. They were transported to Red Sea via Wadi Diit (Figure 9) and formed its delta fan promontory, followed by parallel waves of this promontory that pushed sands onto the beach. Prevailing onshore wind blowed sands inland, where they were accumulated as sand dunes, sheets and barchans (Figure 10(c) and Figure 10(d)). Sand dunes comprise small linear dunes, also called longitudinal or seif dunes, that are oriented parallel to the prevailing wind direction. Their mode of formation is not well understood and various explanations were proposed, including, inter alia, consistent high wind velocities, bi-directional wind regime and helical air flow along the troughs between dunes. They have NNE-SSW trends. The elevation of these sand dunes ranges between 0.5 and $12 \mathrm{~m}$. The prevailing wind direction in the studied area is mainly from the NNE to SSW. However, field observations indicate that sand movement in the study area is from NNE-SSW direction i.e., from the coastal plain of Wadi Diit fan (40 $\mathrm{km}$ from Red Sea shoreline) to basement rocks inland, where sand overrides hill slopes. Sand dunes in the southern part of the study area overlie basement rocks forming barchan.

Mud cracks formation is a natural process in clayey soils upon drying (Figure 10(e)). As drying declines downwards through the sediments, mud cracks have generally been theorized to nucleate near the surface, propagate downward and terminate at depth [20]. Clay content, mineralogy and physical boundary conditions govern the characteristics of a crack network that forms and evolves with decreasing water content [21]. The cracks create weakness zones in a soil mass causing reduction in the overall mechanical strength and increase in the compressibility [22]. Formation of cracks is also one of the important factors effecting hydraulic conductivity of soils. An increase in hydraulic conductivity results in an increase in the rate of transportation of pollutants in the soil.

Crack formation is a natural process observed in clayey soils as a result of decrease in water content. Among the factors effecting crack formation, grain size, temperature, initial water content, thickness and surface characteristics of base material on Ankara Clay [23] as the following results:

1) As the thickness or grain size of the samples increased, the surface area of cracks decreased.

2) As the water content and temperature decreased, the surface area of cracks decreased.

3) As the friction between clay and base material decreased, the surface area of cracks increased. 
The black-sand beach deposits are known as a source of strategic and economic heavy minerals that are considered as raw materials for nuclear industry. Besides, they are considered of thorough importance in many of the metallurgical and engineering industries. The black-sand lens in the present study along the shoreline extends for about $1.5 \mathrm{~km}$ along the Red Sea coast, with a width varies that from 3 to $20 \mathrm{~m}$ and a thickness which changes from 0.4 to $1.0 \mathrm{~m}$ (Figure $10(\mathrm{f})$ ).

\section{Ground Gamma-Ray Spectrometric Survey}

\subsection{Instrumentation}

Radiometric survey for the studied area was carried out using a high-sensitive and well calibrated RS-230 portable gamma-ray spectrometer with Bismuth Germinate Oxide (BGO) detector. This device is manufactured by Radiation Solutions Inc, Ontario, Canada. It is designed to detect gamma-rays, especially for the determination of the contents of potassium (K) in \%, eU in ppm and eTh in ppm, as well as, the total-count (TC) gamma-ray, Ur. The reference radioactive source that was set up with the sensor of the RS-230 is ${ }^{137} \mathrm{Cs}$ [24].

\subsection{Data Acquisition and Survey Design}

The data were collected using a grid pattern, and conducted along E-W equally-spaced profiles. The spacing between survey lines was set at $1.0 \mathrm{~km}$, while the interval between stations was $0.5 \mathrm{~km}$. The measuring time was set by the instrument to be 300 seconds at each station. The station locations were controlled through the use of global positioning systems (GPS) device that has an approximate error in determining the longitude and latitude of less than $5 \%$. After removing noisy observations, the data were dumped into a personal computer as a text file for additional processing.

\subsection{Environmental Monitoring}

The natural radiation is the major source of radiation exposure to man and consists of both internal and external sources. The most significant internal sources are radioactive elements ${ }^{40} \mathrm{~K}$ and ${ }^{222} \mathrm{Rn}$, which are taken into the body. The external sources are cosmic rays and naturally occurring radioactive isotopes of the ${ }^{40} \mathrm{~K}$, as well as the ${ }^{238} \mathrm{U}$ and ${ }^{232} \mathrm{Th}$ decay series. The decay series, some or all of which can be found in the ground, the construction materials and the air. Both internal and external radiation levels vary as functions of the geological materials, type of dwelling and elevation above sea level [25].

An essential part of the present study deals fundamentally with the establishment of the environmental radiation exposure rate (i.e., the natural "terrestrial” gamma radiation) in the study area. This will provide basic information that can be used as a reference to detect the amount of any possible future variation in the natural radioactivity levels in the area that might affect both the terrestrial and atmospheric environments. In addition, the equivalent radiation dose rate was calculated from the radiation exposure rate and established for the study area. This can reveal the degree of hazard on the human being as well as the different effects on and in biological tissues.

Values of eU and eTh in ppm, as well as $\mathrm{K}$, in \%, were converted to activity concentration, Bq/kg, using the conversion factors given by Polish Central Laboratory for Radiological Protection [26]. The specific parent activity of a sample containing $1 \mathrm{ppm}$, by weight, of ${ }^{238} \mathrm{U}$ is $12.35 \mathrm{~Bq} / \mathrm{kg}, 1 \mathrm{ppm}$ of ${ }^{232} \mathrm{Th}$ is $4.06 \mathrm{~Bq} / \mathrm{kg}$ and $1 \%$ of ${ }^{40} \mathrm{~K}$ is $313 \mathrm{~Bq} / \mathrm{kg}$.

The total air absorbed dose rate $(n G y / h)$ due to the mean activity concentrations of ${ }^{238} \mathrm{U},{ }^{232} \mathrm{Th}$ and ${ }^{40} \mathrm{~K}(\mathrm{~Bq} / \mathrm{kg})$ can be calculated using the formula of [27] [28].

$$
D(n \mathrm{~Gy} / h)=0.462 A_{R a}+0.604 A_{T h}+0.0417 A_{K}
$$

where $A_{R a}, A_{T h}$ and $A_{K}$ are the average specific activity of ${ }^{226} \mathrm{Ra},{ }^{232} \mathrm{Th}$ and ${ }^{40} \mathrm{~K}$ in $\mathrm{Bq} / \mathrm{kg}$, respectively. This equation for calculating the absorbed dose rate in air at a height of $1.0 \mathrm{~m}$ above the ground surface from measured radionuclides concentrations in environmental materials derived [29].

The annual effective dose equivalent $(A E D E)$ can be estimated considering the conversion coefficients from absorbed dose rate in air to effective dose received by an adult as 0.7 Sv/Gy [27] taken for environmental exposure to gamma rays of moderate energy. The outdoor occupancy factor is taken equal to 0.2 [27] [28]. The potential annual effective dose equivalent in outdoor ambient is given by the following equation [30]: 


$$
\operatorname{AEDE}(\mu \mathrm{Sv} / \mathrm{y})=D(n \mathrm{~Gy} / \mathrm{h}) \times 10^{-3} \times 8760(\mathrm{~h} / \mathrm{y}) \times 0.2 \times 0.7(\mathrm{~Sv} / \mathrm{Gy}) .
$$

To limit the annual external $\gamma$-ray dose [27] [31] [32] to 1.5 Gy for the samples under investigation, the external hazard index $\left(H_{e x}\right)$ is given by the following equation:

$$
H_{e x}=A_{R a} / 370+A_{T h} / 259+A_{K} / 4810 \leq 1 .
$$

\section{Results and Discussion}

The observed patterns of gamma-ray spectrometry are reflections of their radioactive property of normal constituents in rocks. The measured radio spectrometric data were treated statistically to determine the distribution characteristics of the three radioelements; $\mathrm{K}$ in \%, eU in ppm, eTh in ppm and their activities in different Quaternary sediments in the study area (Table 5 and Figure 12). Contour maps also enable to define the mean absorbed dose rate (D), annual dose effective equivalent $(A E D E)$ and external hazard index $\left(H_{e x}\right)$ (Figures 13-15), respectively.

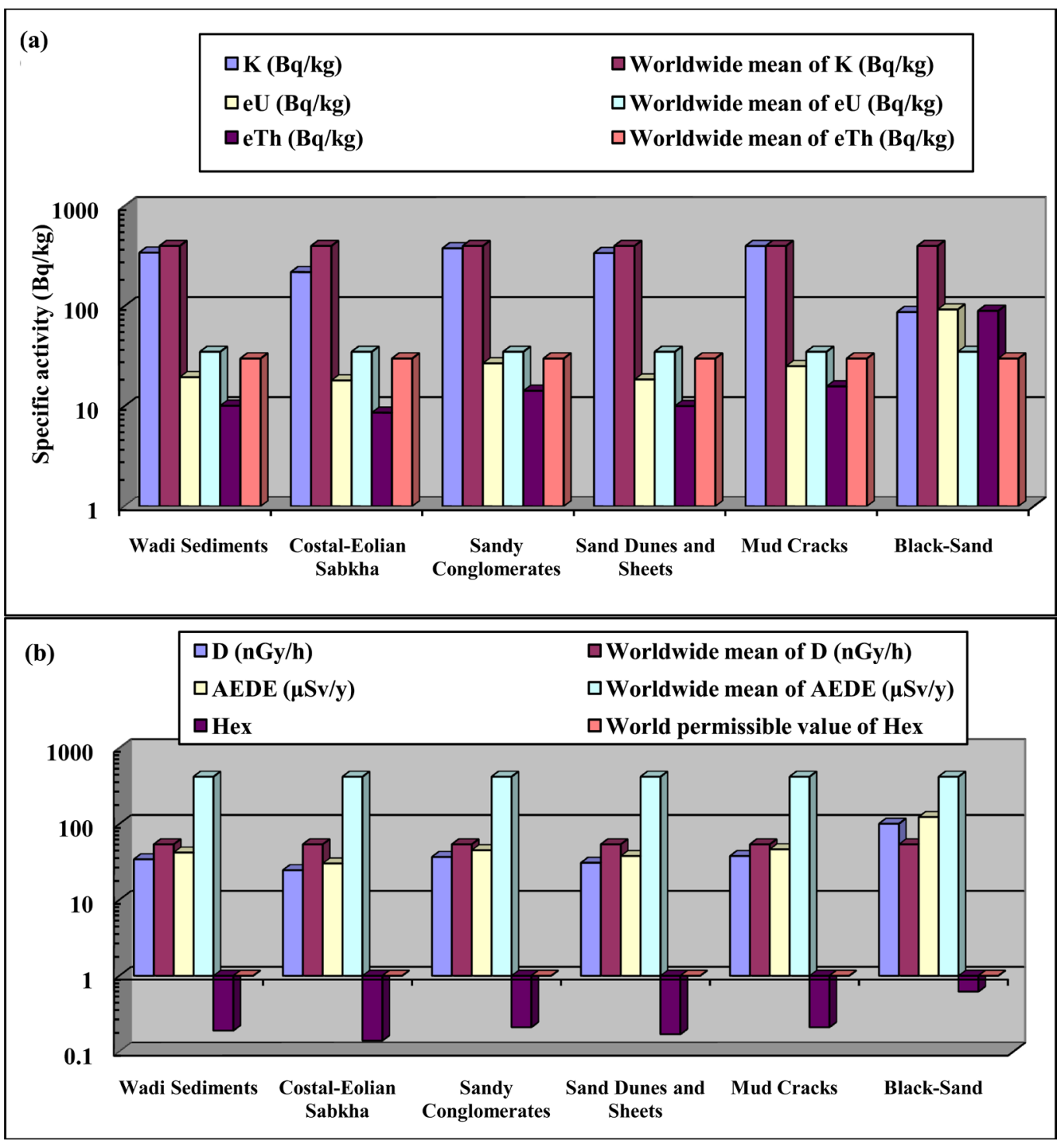

Figure 12. Histograms for Quaternary sediments of Wadi Diit along the Red Sea coast, Egypt. (a) The distributions specific activity concentration of K, eU and eTh. (b) The environmental absorbed dose rate, annual dose effective equivalent and external hazard index. 


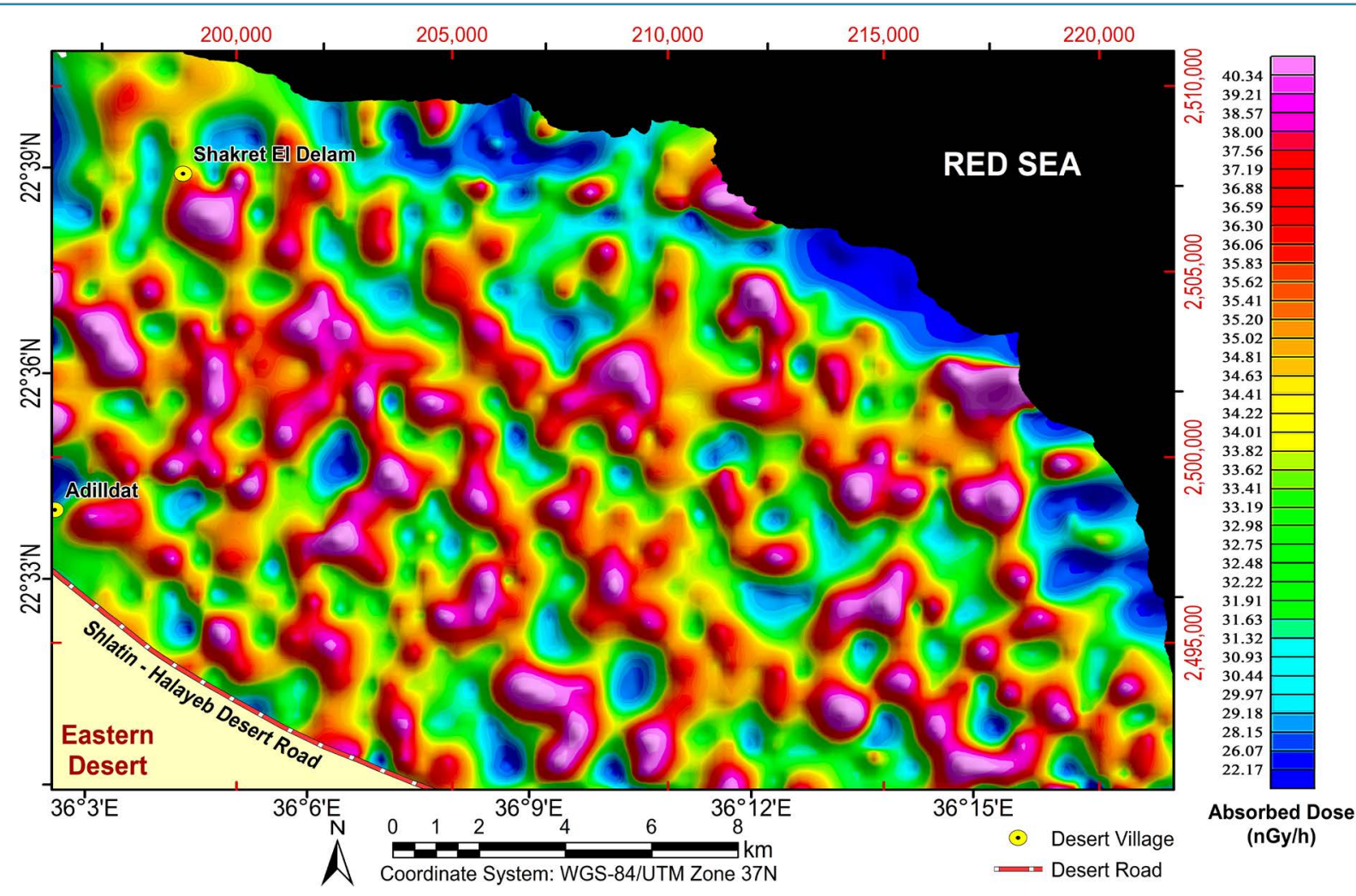

Figure 13. Filled color contour map of absorbed dose rate (nGy/h), Wadi Diit along the Red Sea coast, Egypt.
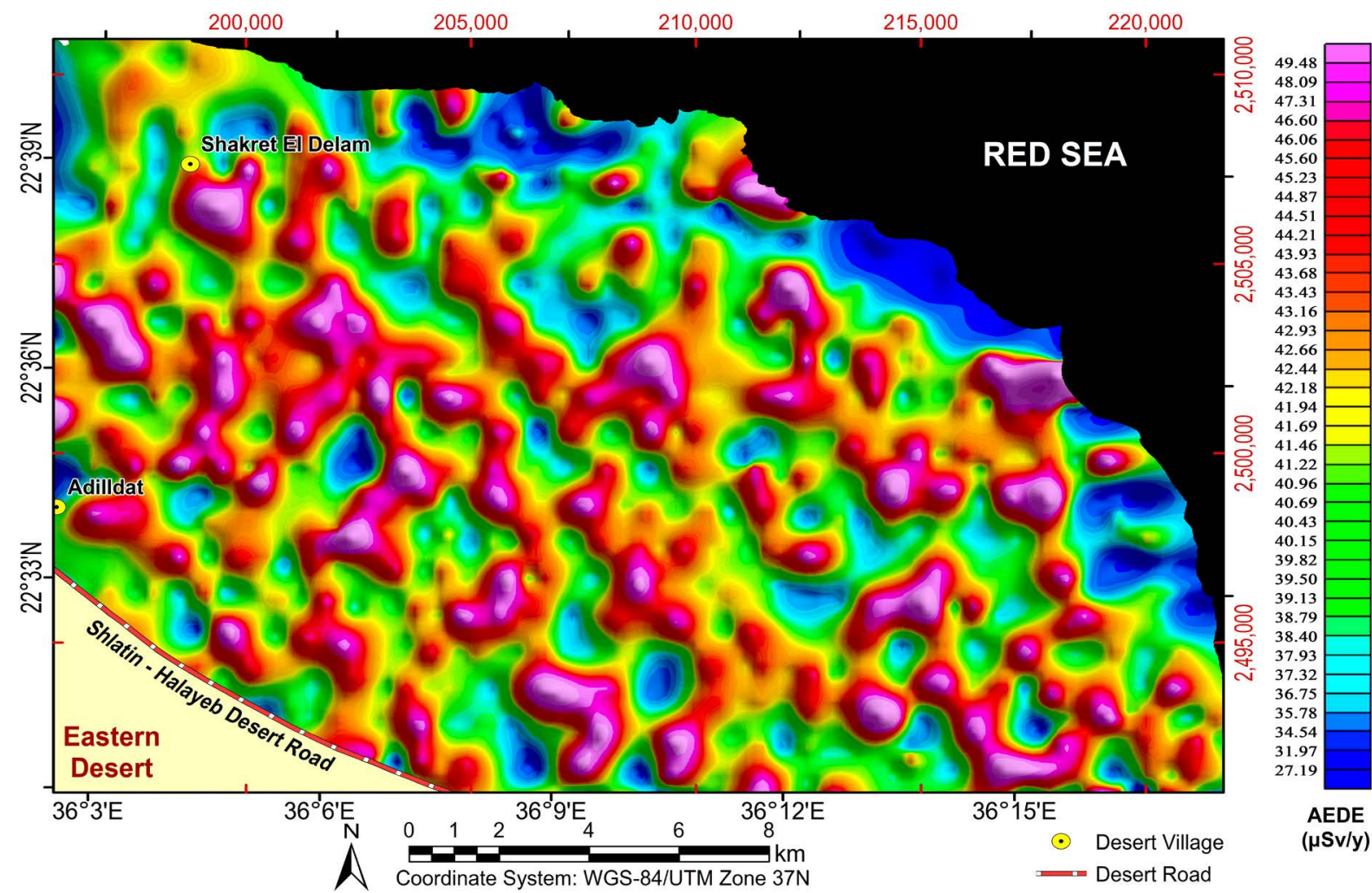

Figure 14. Filled color contour map of annual effective dose equivalent (AEDE, $\mu$ Sv/y), Wadi Diit along the Red Sea coast, Egypt. 


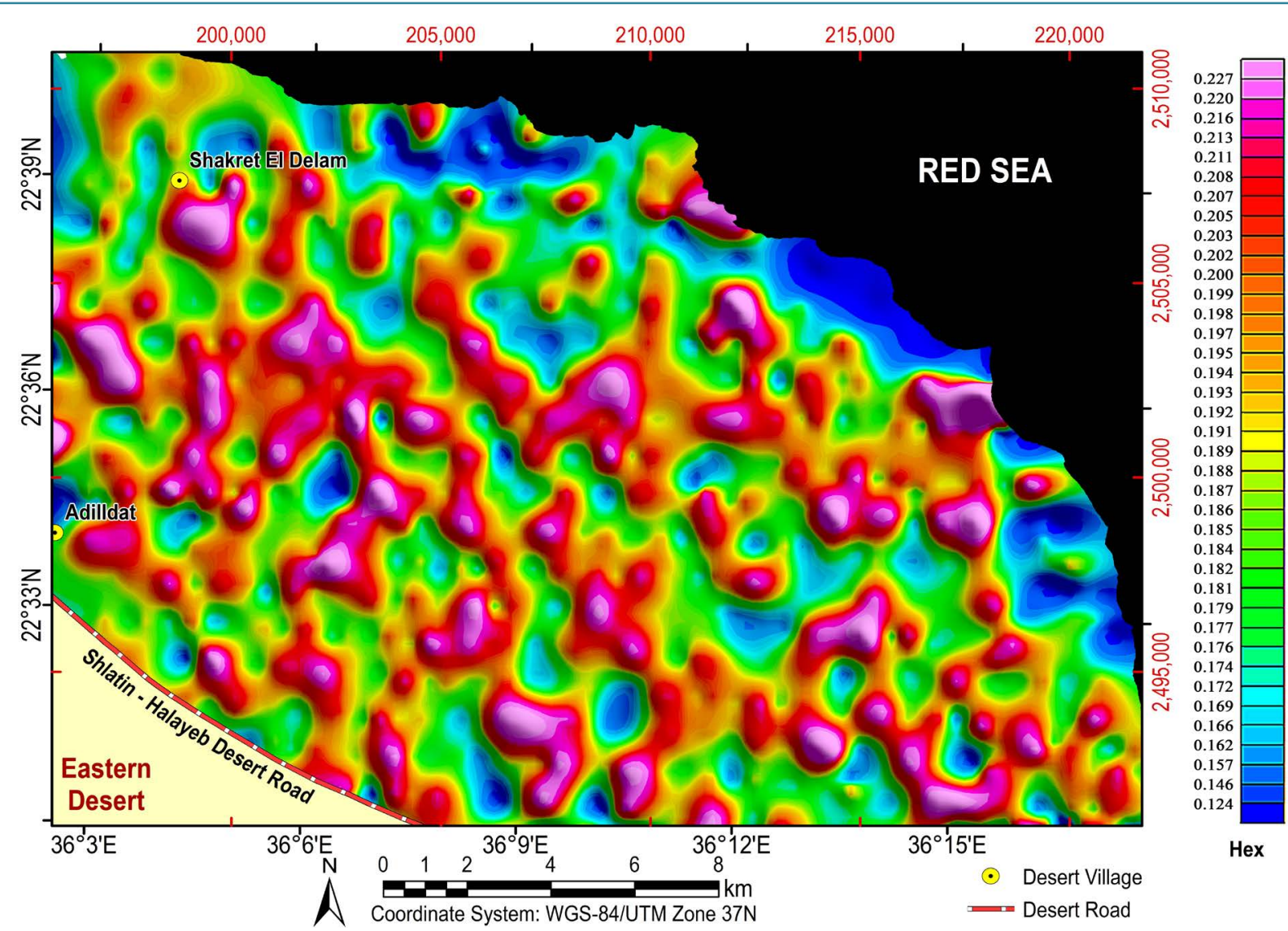

Figure 15. Filled color contour map of the external hazard index $\left(\mathrm{H}_{\mathrm{ex}}\right)$, Wadi Diit along the Red Sea coast, Egypt.

The comparison of K, U and Th specific activities registered by the present study and worldwide mean values Table 5 and Figure 12(a) show that wadi sediments, coastal-eolian sabkhas, sandy conglomerates, sand dunes and sheets and mud cracks have lower contents than permissible Worldwide. Meanwhile, the black-sand lens has higher eU and eTh specific activities than permissible Worldwide related to monazite and zircon [33] but it has low K contents.

The results of the statistical treatment, as illustrated in Table 5, reveal that, the values of mean absorbed dose rate, annual dose effective equivalent and external hazard index for the wadi sediments, costal-eolian sabkhas, sandy conglomerates, sand dunes and sheets and mud cracks remain in safe side and within maximum permissible safe radiation dose rate, without harm to the individual (Figure 12(b)). Meanwhile, the absorbed dose rate of the black-sand lens attains $100.77 \mathrm{nGy} / \mathrm{h}$, which exceeds the world average value of $54 \mathrm{nGy} / \mathrm{h}$ [27] related to the enriched radioactive mineralization monazite and zircon [33] and remains under the world average value for the annual dose effective equivalent and the external hazard index (Figure 12(b)). So, the inhabitants will receive a relatively high radioactive dose related to monazite and zircon.

\subsection{Gamma Absorbed Dose Rate (nGy/h)}

The air absorbed dose rate (nGy/h) is calculated for different Quaternary sediments of Wadi Diit (Table 5) and is also presented on a contour map (Figure 13). It can be seen from the table that the black-sand lens are considered the highest dose rate mean value $100.77 \mathrm{nGy} / \mathrm{h}$. Meanwhile, the lowest dose rate mean value $22.71 \mathrm{nGy} / \mathrm{h}$ associated with costal-eolian sabkhas. Except for the case of black-sand, the mean air absorbed dose rate was calculated to be lower than the [27] value i.e. $54 \mathrm{nGy} / \mathrm{h}$.

\subsection{Annual Effective Dose Equivalent ( $\mu \mathrm{Sv} / \mathrm{y})$}

The annual effective dose equivalent (AEDE) received outdoor by a member is calculated from the absorbed 
Table 5. Summary of the radiospectrometric statistical characteristics of Wadi Diit Quaternary sediments, along the Red Sea, Egypt.

\begin{tabular}{|c|c|c|c|c|c|c|c|c|c|c|}
\hline Stat. par. & TC (Ur) & K (\%) & eU (ppm) & eTh (ppm) & $\mathrm{K}(\mathrm{Bq} / \mathrm{kg})$ & eU (Bq/kg) & eTh $(B q / k g)$ & D (nGy/h). & $\operatorname{AEDE}(\mu \mathrm{Sv} / \mathrm{y})$ & $\mathrm{H}_{\mathrm{ex}}$ \\
\hline \multicolumn{11}{|c|}{ Wadi Sediments } \\
\hline Min. & 2.80 & 0.40 & 0.30 & 1.20 & 125.20 & 3.71 & 4.87 & 23.91 & 28.21 & 0.13 \\
\hline Max. & 4.40 & 1.51 & 4.10 & 5.20 & 472.63 & 50.64 & 21.11 & 55.85 & 68.50 & 0.32 \\
\hline $\mathrm{X}$ & 3.37 & 1.10 & 1.58 & 2.49 & 342.89 & 19.51 & 10.12 & 29.42 & 36.06 & 0.16 \\
\hline S & 0.21 & 0.17 & 0.57 & 0.79 & 54.14 & 7.01 & 3.20 & 2.00 & 2.61 & 0.01 \\
\hline $\mathrm{X}+3 \mathrm{~S}$ & 3.99 & 1.61 & 3.28 & 4.86 & 505.32 & 40.54 & 19.72 & 35.42 & 43.88 & 0.20 \\
\hline No. & & & & & & 176 & & & & \\
\hline
\end{tabular}

\begin{tabular}{ccccccccccc}
\hline \multicolumn{10}{c}{ Costal-Eolian Sabkhas } \\
\hline Min. & 1.60 & 0.20 & 0.40 & 0.10 & 62.60 & 4.94 & 0.41 & 14.28 & 17.51 & 0.08 \\
Max. & 4.00 & 1.30 & 3.30 & 4.40 & 406.90 & 40.76 & 17.86 & 35.25 & 43.23 & 0.20 \\
X & 2.60 & 0.70 & 1.47 & 2.12 & 219.10 & 18.10 & 8.62 & 22.71 & 27.81 & 0.13 \\
S & 0.50 & 0.22 & 0.69 & 0.89 & 70.27 & 8.55 & 3.60 & 4.34 & 5.33 & 0.03 \\
X + 3S & 4.09 & 1.37 & 3.54 & 4.78 & 429.90 & 43.75 & 19.42 & 35.74 & 43.81 & 0.20 \\
No. & & & & & & 209 & & & &
\end{tabular}

\begin{tabular}{ccccccccccc}
\hline & \multicolumn{7}{c}{ Sandy Conglomerates } \\
\hline Min. & 3.50 & 0.90 & 0.90 & 1.10 & 281.70 & 11.12 & 4.47 & 29.54 & 36.23 & 0.17 \\
Max. & 5.30 & 1.50 & 4.10 & 5.40 & 469.50 & 50.64 & 21.92 & 46.99 & 57.63 & 0.26 \\
X & 4.22 & 1.21 & 2.17 & 3.51 & 378.63 & 26.84 & 14.26 & 36.80 & 45.13 & 0.21 \\
S & 0.40 & 0.14 & 0.62 & 0.88 & 43.80 & 7.68 & 3.57 & 3.63 & 4.46 & 0.02 \\
X + 3S & 5.41 & 1.63 & 4.04 & 6.15 & 510.02 & 49.89 & 24.96 & 47.70 & 58.50 & 0.27 \\
No. & & & & & & 48 & & & &
\end{tabular}

\begin{tabular}{|c|c|c|c|c|c|c|c|c|c|c|}
\hline \multicolumn{11}{|c|}{ Sand Dunes and Sheets } \\
\hline Min. & 2.70 & 0.60 & 0.30 & 1.20 & 187.80 & 3.71 & 4.87 & 23.82 & 28.21 & 0.13 \\
\hline Max. & 4.30 & 1.47 & 3.00 & 4.40 & 460.11 & 37.05 & 17.86 & 47.09 & 57.75 & 0.26 \\
\hline $\mathrm{X}$ & 3.31 & 1.08 & 1.50 & 2.47 & 339.59 & 18.49 & 10.04 & 28.77 & 35.18 & 0.16 \\
\hline $\mathrm{S}$ & 0.34 & 0.19 & 0.50 & 0.77 & 59.92 & 6.12 & 3.11 & 2.96 & 3.72 & 0.02 \\
\hline $\mathrm{X}+3 \mathrm{~S}$ & 4.33 & 1.66 & 2.98 & 4.77 & 519.35 & 36.84 & 19.37 & 37.64 & 46.34 & 0.21 \\
\hline No. & \multicolumn{10}{|c|}{335} \\
\hline \multicolumn{11}{|c|}{ Mud Cracks } \\
\hline Min. & 3.30 & 1.00 & 1.10 & 1.90 & 313.00 & 13.59 & 7.71 & 29.05 & 35.62 & 0.16 \\
\hline Max. & 5.60 & 1.49 & 3.20 & 5.70 & 466.37 & 39.52 & 23.14 & 51.68 & 63.38 & 0.29 \\
\hline $\mathrm{X}$ & 4.35 & 1.28 & 2.04 & 3.89 & 399.54 & 25.14 & 15.79 & 37.81 & 46.37 & 0.21 \\
\hline $\mathrm{S}$ & 0.71 & 0.14 & 0.62 & 1.20 & 44.99 & 7.65 & 4.87 & 6.18 & 7.58 & 0.04 \\
\hline$x+3 S$ & 6.47 & 1.71 & 3.89 & 7.49 & 534.51 & 48.09 & 30.40 & 56.34 & 69.10 & 0.32 \\
\hline No. & & & & & & 54 & & & & \\
\hline \multicolumn{11}{|c|}{ Black-Sand } \\
\hline Min. & 8.90 & 0.10 & 5.10 & 14.30 & 31.30 & 62.99 & 58.06 & 75.84 & 93.02 & 0.46 \\
\hline Max. & 15.40 & 0.70 & 10.90 & 35.30 & 219.10 & 134.62 & 143.32 & 129.40 & 158.70 & 0.79 \\
\hline $\mathrm{X}$ & 11.93 & 0.28 & 7.51 & 22.14 & 87.42 & 92.71 & 89.89 & 100.77 & 123.59 & 0.62 \\
\hline S & 1.89 & 0.14 & 1.49 & 6.09 & 43.77 & 18.43 & 24.73 & 15.14 & 18.57 & 0.10 \\
\hline $\mathrm{X}+3 \mathrm{~S}$ & 17.61 & 0.70 & 11.98 & 40.41 & 218.74 & 147.99 & 164.07 & 146.19 & 179.29 & 0.90 \\
\hline No. & & & & & & 34 & & & & \\
\hline
\end{tabular}

Stat. par.: statistical parameters; D: absorbed dose rate, AEDE: annual dose effective equivalent, $\mathrm{H}_{\mathrm{ex}}$ : external hazard index, Min.: minimum; Max.: maximum; X: arithmetic mean; S, standard deviation and No.: number of stations. 
dose rate through the application of dose conversion factor of $0.7 \mathrm{~Sv} / \mathrm{Gy}$ and the occupancy factor for outdoor of 0.2. The results were presented on a shaded relief contour map (Figure 14), which shows that AEDE value oscillates between $17.51 \mu \mathrm{Sv} / \mathrm{y}$ and $158.7 \mu \mathrm{Sv} / \mathrm{y}$. According to [34], the world average annual effective dose equivalent reaches $2.8 \mathrm{mSv} / \mathrm{y}$, with the external gamma-ray contribution of $15 \%$ (i.e., $420 \mu \mathrm{Sv} / \mathrm{y}$ ). From Table 5, it can be seen that AEDE values for Wadi Diit area are generally below this world average value.

\subsection{External Hazard Index}

The results obtained for $\mathrm{H}_{\mathrm{ex}}$ were presented on a shaded relief contour map (Figure 15). The $\mathrm{H}_{\mathrm{ex}}$ map involves a minimum value of 0.08 associated with costal-eolian sabkhas and a maximum value of 0.79 coincided with black-sand lens. The obtained values of $\mathrm{H}_{\mathrm{ex}}$ for the area under consideration (Table 5) are found to be less than the world permissible value of unity [28]. This indicates that the values will not lead to respiratory diseases, such as: asthma and cancer and external diseases such as: erythema, skin cancer and cataracts [35].

\section{Conclusions and Recommendations}

A detailed geologic map (scale 1:100,000) of the different landcover units of Wadi Diit area was obtained by the analysis of Landsat 8 OLI satellite data. Maximum likelihood supervised classification followed by MajorityMinority analysis was applied successfully (with $89.51 \%$ overall accuracy) based on selected ROIs representing the different lithologic units. This shows the potential of remote sensing technique for geologic mapping in hard accessible environs like the study area. The integrated work between image processing of Landsat 8 data and detailed field investigation show that the exposed rock units at Wdi Diit fan are represented by unconsolidated wadi sediments, costal-eolian sabkhas, sandy conglomerates, dunes and sheets, mud cracks and black-sand lens. sand

The absorbed dose rate (D), annual effective dose equivalent (AEDE) and external hazard index $\left(\mathrm{H}_{\mathrm{ex}}\right)$ from the terrestrial gamma-radiation of Quaternary sediments were found to be within the recommended international limits, with no significant health threat to human lives and, therefore, the environment is said to be radiological hazard safe.

From the results of the present work, the authors recommend that the inhabitants of Adilldat and Shakret El-Delam villages at Wadi Diit fan can spread horizontally through the fan, except the black-sand lens, because it is considered as one of the most safety environments along the Red Sea coast. On the other hand, black-sand lens along the Red Sea coast of the studied area is not recommended to be used in building materials, because the absorbed dose rate of the black-sand lens attains $100.77 \mathrm{nGy} / \mathrm{h}$ that exceed the world permissible value.

\section{Acknowledgements}

The authors would like to express their gratitude to Prof. Dr. Ahmed A. Ammar, Emeritus Professor of applied geophysics, Exploration Sector, Nuclear Materials Authority of Egypt, for constructive critical revising of the manuscript for his revisions and fruitful discussions. They also, cordially thank the reviewers of this work for their comments and recommendations.

\section{References}

[1] Xhixha, G. (2012) Advanced Gamma-Ray Spectrometry for Environmental Radioactivity Monitoring. PhD Thesis, University of Ferrara, Faculty of Mathematics, Physics and Natural Sciences, Ferrara, 147 p.

[2] Rudnick, R.L. and Gao, S. (2003) Composition of the Continental Crust. Treatise on Geochemistry, 3, 1-64. http://dx.doi.org/10.1016/B0-08-043751-6/03016-4

[3] Alanazi, H.A. and Ghrefat, H.A. (2013) Spectral Analysis of Multispectral Landsat 7 ETM+ and ASTER Data for Mapping Land Cover at Qurayah Sabkha, Northern Saudi Arabia. Journal of the Indian Society of Remote Sensing, 41, 833-844. http://dx.doi.org/10.1007/s12524-013-0291-2

[4] Bryant, R.G. (1996) Validated Linear Mixture Modeling of Landsat TM Data for Mapping Evaporite Minerals on a Playa Surface: Methods and Application. International Journal of Remote Sensing, 17, 315-330. http://dx.doi.org/10.1080/01431169608949008

[5] Castañeda, C., Herrero, J. and Casterad, M.A. (2005) Facies Identification within the Playa Lakes of the Monegros Desert, Spain, with Field and Satellite Data. Catena, 63, 39-63. http://dx.doi.org/10.1016/j.catena.2005.05.011 
[6] Kodikara, R.L., Woldai, T., Ruitenbeek, F.J.A., Kuria, Z., Meer, F., Shepherd, K.D. and Hummel, G.J. (2011) Hyperspectral Remote Sensing of Evaporate Minerals and Associated Sediments in Lake Magadi Area, Kenya. International Journal of Applied Earth Observation and Geoinformation, 14, 22-32. http://dx.doi.org/10.1016/j.jag.2011.08.009

[7] Kaiser, M.F., Aziz, M.A. and Ghieth, B.M. (2014) Environmental Hazards and Distribution of Radioactive Black Sand along the Rosetta Coastal Zone in Egypt Using Airborne Spectrometric and Remote Sensing Data. Journal of Environmental Radioactivity, 137, 71-78. http://dx.doi.org/10.1016/j.jenvrad.2014.06.006

[8] Chapman, J.E., Rothery, D.A., Francis, P.W. and Pontual, A. (1989) Remote Sensing of Evaporite Mineral Zonation in Salt Flats (Salars). International Journal of Remote Sensing, 10, 245-255. http://dx.doi.org/10.1080/01431168908903860

[9] Ghrefat, H.A. and Goodell, P.C. (2011) Land Cover Mapping at Alkali Flat and Lake Lucero, White Sands, New Mexico, USA Using Multi-Temporal and Multi-Spectral Remote Sensing Data. International Journal of Applied Earth Observation and Geoinformation, 13, 616-625. http://dx.doi.org/10.1016/j.jag.2011.03.009

[10] Irons, J.R., Dwyer, J.L. and Barsi, J.A. (2012) The Next Landsat Satellite: The Landsat Data Continuity Mission. Remote Sensing of Environment, 122, 11-21. http://dx.doi.org/10.1016/j.rse.2011.08.026

[11] Ding, Y., Zhao, K., Zheng, X. and Jiang, T. (2014) Temporal Dynamics of Spatial Heterogeneity over Cropland Quantified by Time-Series NDVI, Near Infrared and Red Reflectance of Landsat 8 OLI Imagery. International Journal of Applied Earth Observation and Geoinformation, 30, 139-145. http://dx.doi.org/10.1016/j.jag.2014.01.009

[12] USGS (2013) Landsat 8. In: Center, E.R.O.S., Ed., Fact Sheet 2013-3060, USGS, Reston, 4 p.

[13] Vanhellemont, Q. and Ruddick, K. (2014) Turbid Wakes Associated with Offshore Wind Turbines Observed with Landsat 8. Remote Sensing of Environment, 145, 105-115. http://dx.doi.org/10.1016/j.rse.2014.01.009

[14] Green, A.A., Berman, M., Switzer, P. and Craig, M.D.A (1988) Transformation for Ordering Multispectral Data in Terms of Image Quality with Implications for Noise Removal. IEEE Transactions on Geoscience and Remote Sensing, 26, 65-74. http://dx.doi.org/10.1109/36.3001

[15] ENVI, ENVI Tutorial (2013) Exelis Visual Information Solutions. Boulder, Colorado.

[16] Jensen, J.R. (2005) Introductory Digital Image Processing: A Remote Sensing Perspective. Prentice Hall, Upper Saddle River.

[17] Liu, J.G. and Mason, P. (2009) Essential Image Processing and GIS for Remote Sensing. John Wiley \& Sons Ltd., Hoboken. http://dx.doi.org/10.1002/9781118687963

[18] Handford, C.R. (1981) Genetic Characterization of Recent and Ancient Sabkha Systems. Gulf Coast Association of Geological Societies Transactions, 31, 307-308.

[19] Warren, J.K. (2006) Evaporites: Sediments, Resources and Hydrocarbons: Sediments, Resources, and Hydrocarbons. Springer, Berlin, 1052 p. http://dx.doi.org/10.1007/3-540-32344-9

[20] Weinberger, R. (1999) Initiation and Growth of Cracks during Desiccation of Stratified Muddy Sediments. Journal of Structural Geology, 21, 379-386. http://dx.doi.org/10.1016/S0191-8141(99)00029-2

[21] Vogel, H.J., Hoffmann, H., Leopold, A. and Roth, K. (2005) Studies of Crack Dynamics in Clay Soil: II. A Physically Based Model for Crack Formation. Geoderma, 125, 213-223. http://dx.doi.org/10.1016/j.geoderma.2004.07.008

[22] Tang, C., Shi, B., Liu, C., Zhao, L. and Wang, B. (2008) Influencing Factors of Geometrical Structure of Surface Shrinkage Cracks in Clayey Soils. Engineering Geology, 101, 204-217. http://dx.doi.org/10.1016/j.enggeo.2008.05.005

[23] Selen, F. and Türer, D. (2011) Factors Effecting Mud Crack Formation in Ankara Clay. World Academy of Science, Engineering and Technology, 5, 165-167.

[24] RS-230 (2009) Manual Radiation Solutions Inc. RS-125/230 User Manual-Ver. 2.0. 51 p.

[25] IAEA (International Atomic Energy Agency) (1990) The Use of Gamma-Ray Data to Define the Natural Radiation Environment. Technical Reports, Series No. 566, Vienna, Austria, 48 p.

[26] Malczewski, D., Taper, L. and Dorda, J. (2004) Assessment of Natural and Anthropogenic Radioactivity Levels in Rocks and Soils in the Environs of Swieradow Zdroj in Sudetes, Poland by in Situ Gamma-Ray Spectrometry. Journal of Environmental Radioactivity, 73, 233-245. http://dx.doi.org/10.1016/j.jenvrad.2003.08.010

[27] UNSCEAR (United Nations Scientific Committee on the Effects of Atomic Radiation) (2000) United Nations Scientific Committee on the Effects of Atomic Radiation Report to the General Assembly, with Annexes. Sources and Effects of Ionizing Radiation, Sources. Vol. 1, United Nation, New York, 654 p.

[28] Örgün, Y., Altinsoy, N., Sahin, S.Y., Gungor, Y., Gultekin, A.H., Karahan, G. and Karacik, Z. (2007) Natural and Anthropogenic Radionuclides in Rocks and Beach Sands from Ezine Region (Canakkale), Western Anatolia, Turkey. Applied Radiation and Isotopes, 65, 739-747. http://dx.doi.org/10.1016/j.apradiso.2006.06.011

[29] Beck, H.L., Decompo, J. and Gologak, J. (1972) In Situ Ge(Li) and Nai(Tl) Gamma Ray Spectrometry. Health and 
Safety Laboratory Aec, Report HASl285, New York.

[30] UNSCEAR (United Nations Scientific Committee on the Effects of Atomic Radiation) (1988) The United Nation Scientific Committee on the Effects of Atomic Radiation Sources to the General Assembly with Annexes, Effects and Risks of Ionizing Radiation. United Nations Publication, New York.

[31] Saito, K. and Jacob, P. (1995) Gamma Ray Fields in the Air Due to Sources in the Ground. Radiation Protection Dosimetry, 58, 29-45.

[32] Saito, K., Petoussi-Henss, N. and Zankl, M. (1998) Calculation of the Effective Dose and Its Variation from Environmental Gamma Ray Sources. Health Physics, 74, 698-706. http://dx.doi.org/10.1097/00004032-199806000-00007

[33] Ibrahim, T.M., Abu Halawa, A., Ali, K.G. and Gaafar, I.M. (2009) Occurrence of Black Sand Deposits on the Red Sea Coastal Plain of Wadi Diit, South Eastern Desert, Egypt: A Preliminary Study. Journal of the Sedimentological Society of Egypt, 17, 107-116.

[34] Green, B.M.R., Lomas, P.R. and O’Riordan, M.C. (1992) Radon in Dwellings in England. Radon in Dwellings in England, NRPB-R254.

[35] Avwiri, G.O., Osimobi, J.C. and Agbalagba, E.O. (2012) Evaluation of Radiation Hazard Indices and Excess Lifetime Cancer Risk Due to Natural Radioactivity in Soil Profile of Udi and Ezeagu Local Government Areas of Enugu State, Nigeria. Comprehensive Journal of Environmental and Earth Sciences, 1, 1-10.

\section{Submit or recommend next manuscript to SCIRP and we will provide best service for you:}

Accepting pre-submission inquiries through Email, Facebook, LinkedIn, Twitter, etc. A wide selection of journals (inclusive of 9 subjects, more than 200 journals)

Providing 24-hour high-quality service

User-friendly online submission system

Fair and swift peer-review system

Efficient typesetting and proofreading procedure

Display of the result of downloads and visits, as well as the number of cited articles

Maximum dissemination of your research work

Submit your manuscript at: http://papersubmission.scirp.org/ 